\title{
QUALITY OF ARCHITECUTRE AND PUBLIC SPACES AS A RESULT OF COUNTRY'S PUBLIC PROCURMENT CULTURE
}

\author{
MACIEJ WOJCIECH KOWALCZYK \\ Faculty of Architecture, Warsaw University of Technology, \\ Koszykowa 55, 00-659 Warszawa \\ E-mail address: mckowalczyk@gmail.com \\ ORCID: https://orcid.org/0000-0002-8396-9655
}

\begin{abstract}
Thesis. The quality of emerging public spaces and buildings is related to the public procurement culture of a given country. One can not count on achieving high quality public space, architecture without a democratic debate on the subject. The space, which is decided only by a small group of technocrats, the project, which is subject to only the price criterion, results in accidental solutions.

Methods. The article shows the basic methods provided for by law to select public projects. Indicates the advantages and disadvantages of individual processes. It analyzes examples of appreciated realizations that arose as a result of architectural competitions.

Results. Tools provided in the public procurement law, such as social debate in the form of architectural competitions build a better quality of the created space. The existence of such a link is proven by the awards granted to spaces completed under such processes.

Conclusions. Projects created using these tools account for less than $1 \%$ of all public procurement in Poland. One should strive for a change that would promote these processes, especially outside large cities, thus increasing the quality of spaces created from public money.

Key words: architecture, building culture, bakultur, architectural design contest, architectural competition, competition practices, public procurement, procurement of design services
\end{abstract}

\section{PUBLIC INVESTMENT}

Public space or public buildings i.e. squares, court buildings, universities, libraries, schools or hospitals constitute a common good. Their shape is of interest to both the authorities and the users of this space. The initiator of the change process, i.e. construction, conversion of a given space, can be each side, but it is the public / executive authority that is responsible for the organization 
of the transformation process itself. Due to a need of the transparency, this process is limited by the legal framework, which in many European countries is a public procurement law. It describes several instruments that a public investor can use. However, the tools mainly used in the field of architecture and spatial planning include the tender and the competition. While in the tender the main criteria are the price or the time of realization, this elements do not matter in the competition. The main subject of interest is not the contractor of a given service but the project which will have an impact on the space. "By in depth evaluation, an independent jury selects the best solution out of a variety proposed by different architects. The criteria applied are defined beforehand and include functional, economic, environmental, energetic and esthetic aspects. Project orientated means that the procurement of the service is based on the quality of the future project, which is already possible to evaluate in beforehand" (ACE, 2018).

Hence, it can be concluded that in a country where the broadly understood competition procedure is promoted, a better new design space is created than in a country where the project is selected through a tender procedure mainly based on the price of the design service. Not without reason, in terms of the quality of architecture or public spaces, countries such as Denmark, the Netherlands, Switzerland, Germany or Finland are so significant. Poland, despite the long tradition of organizing competitions is not included in this group. However, it should be noted that awareness of the importance of this procedure is growing. In 2017, the Warsaw authorities decided that all newly created objects must be selected through architectural design contest (Miasto St. Warszawa, 2017).

\section{DESIGNING WITHIN THE FRAME OF PUBLIC PROCUREMENT LAW}

In order to better understand the topic, it is necessary to define the main differences between the tender and the competition as well as the practice of their application in the framework of providing architectural and urban design services. Both form a public procurement formulas, but they have a different character due to their use.

In the EU countries there is a common EU directive 2014/ 25 / EU (2014), which indicates in which direction all national regulations should be adjusted. Poland has adjusted its regulations through the Polish Public Procurement Act in 2017. According to the definitions indicated in the 10th parpagraph of the document "the primary procedures for awarding contracts are open tendering and restricted tendering" (Ustawa Prawo Zamówień Publicznych, 2017).

In tenders for architectural services a key role is played by criteria such as: price, deadline, knowledge and experience. According to the UZP (Public Procurement Office) report on the applied criteria, it is usually the price and other 
additional criterion (85-90\% of cases) that are used (Urząd Zamówień Publicznych, 2018). However, there are no detailed statistics regarding only tenders for architectural services. The author's observations seem to confirm the fact that the most commonly used criteria are the price and time of execution as easily measurable factors. A criterion such as knowledge and experience is definitely less frequently used.

Architectural competition, in turn, in legal terms is a public promise, originally resulting from art. 919-921 of the Civil Code (Kodeks Cywilny, 1963). In Polish law, the competition procedure is regulated in detail by the Public Procurement Law. - Art. 110 "A design contest is a public promise, in which by means of a public notice the contracting authority promises a prize for the execution and transfer of rights to the design selected by the jury, in particular in the fields of spatial planning, town planning, architecture and construction, and data processing" (Ustawa Prawo Zamówień Publicznych, 2017).

In Poland, in 2018, from all the public procurement procedures, the tender is a formula that constituted $99.35 \%$, the competition in turn only $0.07 \%$ (Public Procurement Office, 2018). Again, there are no studies that would indicate how much of the above orders concerned only orders for architectural services. However, from the observation of the market one should suspect that the statistics are crushing for tenders.

For comparison, the statistics of the German web portal Competitionline dedicated to orders for architectural services in Germany, reports that among public procurement orders for design services: $0.4 \%$ are open competitions, $3 \%$ are closed competitions, $1.5 \%$ are invited competitions (Bonnkirch, 2017). However, it should be taken into account that some of them are contests for other engineering services.

When comparing both procedures, regardless of the country, the practical side should be noted. The tender is a less demanding procedure than the competition. It takes less time, is simpler organizationally, it is cheaper, because it can be usually organized using own resources and without external specialists. There is also a lower risk of cancellations due to the rather simple, non-anonymous procedure based on scoring.

The competition, on the other hand, takes more time, is more complex organizationally, it is also more expensive due to the need to involve specialists from outside (jury, experts) and also requires a budget foreseen for prizes. In addition, the procedure is more sensitive due to its multistage nature and often the requirement of anonymity.

So what is the reason for the competitions? As it has been proven, the competition, despite the greater investment in the initial phase as well as the longer time devoted to the procedure itself, brings investors a greater security and optimization of the design process, due to the review of design solutions and earlier received target design solution (Achatzi, 2017). Additionally, the public spaces and facilities completed as a result of the competition are later more appreciated by the users as well as a professionals. 


\section{CASE STUDIES}

In Poland, several prestigious awards for completed architectural objects are organized every year. The most serious of these are the "Architectural Award of the Year" organized by Polityka magazine and "SARP Award of the Year". The architectural award of the Polityka magazine is awarded in two categories - the Grand Prix in a secret ballot by a professional jury and the Readers' Award, where the readers of the magazine vote online. The list of objects submitted for the competition is based on the recommendation of professional associations and the selection of the magazine itself. The prize enjoys great interest and is a media event. In 2011-2018, in terms of prizes in competitions / tenders, it appeared in accordance with the table below (Tab. 1).

Table 1.

Polityka's magazine Architectural Award of the Year - grand prix and readers' award.

\begin{tabular}{c|lc|lc} 
Date & \multicolumn{1}{|c|}{ grand prix } & procedure & \multicolumn{1}{c}{ readers' award } & procedure \\
\hline 2018 & $\begin{array}{l}\text { Hala Cracovii, } \\
\text { Kraków }\end{array}$ & competition & $\begin{array}{l}\text { Bobrowisko, } \\
\text { Stary Sącz }\end{array}$ & design\&build \\
\hline 2017 & $\begin{array}{l}\text { WRIT, } \\
\text { Katowice }\end{array}$ & competition & $\begin{array}{l}\text { Bałtyk Office, } \\
\text { Poznań }\end{array}$ & private commission \\
\hline 2016 & $\begin{array}{l}\text { Centrum Przełomy, } \\
\text { Szczecin }\end{array}$ & competition & $\begin{array}{l}\text { Nabrzeże jez. Ukiel, } \\
\text { Olsztyn }\end{array}$ & competition \\
\hline 2015 & $\begin{array}{l}\text { MCK, } \\
\text { Katowice }\end{array}$ & competition & $\begin{array}{l}\text { MCK, } \\
\text { Katowice }\end{array}$ & competition \\
\hline 2014 & $\begin{array}{l}\text { Cricoteka, } \\
\text { Kraków }\end{array}$ & competition & $\begin{array}{l}\text { NOSPR, } \\
\text { Katowice }\end{array}$ & competition \\
\hline 2013 & $\begin{array}{l}\text { SDK, } \\
\text { Warszawa }\end{array}$ & competition & $\begin{array}{l}\text { MHŻP, } \\
\text { Warszawa }\end{array}$ & competition \\
\hline 2012 & $\begin{array}{l}\text { Miejska przystań, } \\
\text { Bydgoszcz }\end{array}$ & competition & $\begin{array}{l}\text { Miejska przystań, } \\
\text { Bydgoszcz }\end{array}$ & competition \\
\hline 2011 & $\begin{array}{l}\text { CINiBA, } \\
\text { Katowice }\end{array}$ & competition & CINiBA, & competiton \\
\end{tabular}

Source: Tygodnik Polityka. Retrieved from: https://www.polityka.pl/TygodnikPolityka/architektura.

The SARP Award of the Year is in turn awarded in numerous categories, of which one Grand Prix is chosen. Entries for the competition are open. The award is granted by a professional association and therefore enjoys great interest especially among its members. In 2011-2018, in terms of prizes in competitions / tenders, it appeared in accordance with the table below (Tab. 2). 
Table 2.

SARP Award of the Year - grand prix.

\begin{tabular}{l|ll}
\multicolumn{1}{c|}{ date } & \multicolumn{1}{|c}{ grand prix } & \multicolumn{1}{c}{ procedure } \\
\hline 2018 & Hala Cracovii, Kraków & competition \\
\hline 2017 & Teatr w Budowie, Lublin & competition \\
\hline 2016 & Centrum Przełomy, Szczecin & competition \\
\hline 2015 & MCK, Katowice & competition \\
\hline 2014 & Cricoteka, Kraków & competition \\
\hline $2012-13$ & ECM, Lusławice & semi-private commission \\
\hline 2011 & CINiBA, Katowice & competition \\
\hline
\end{tabular}

Source: Stowarzyszenie Architektów Polskich. Retrieved from: http://sarp.org.pl.

It is also worth paying attention to the architectural prize of the Mayor of St. Warsaw. This prize is awarded in many categories, among which the Grand Prix and the Residents' Prize are selected. The jury consists of a multidisciplinary team consisting of professionals, journalists and city's representatives. Applications for the prize are open. In 2015-2018, projects that were created as a result of the following procedures were awarded (Tab. 3):

Table 3.

Architectural prize of the Mayor of Warsaw - grand prix and residents' award.

\begin{tabular}{l|ll|ll} 
Date & grand prix & procedure & \multicolumn{1}{|c}{ residents' award } & procedure \\
\hline 2017 & Bulwary Wiślane & competition & Bulwary Wiślane & competition \\
\hline 2016 & Hala Koszyki & $\begin{array}{l}\text { private } \\
\text { commission }\end{array}$ & Kładka Żerań (modernizacja) & tender \\
\hline 2015 & Wystawa WWB7 & competition & Biblioteka Koszykowa & competition \\
\hline
\end{tabular}

Source: Urząd Miasta St. Warszawa. Retrieved from: http:/ / www.nagroda-architektoniczna.pl.

Analyzing the above examples of three prizes awarded to completed objects and public spaces, it should be stated that the vast majority of objects that have been awarded are objects selected through the architectural design contest. The objects selected in the tender procedure on the list represent two objects, including one modernization of the existing facility (Kładka Żerań) and Bobrowisko in Nowy Sącz designed in the design\&build process, where the contractor was selected in a tender. In addition, you can distinguish objects that were comissioned directly by private investors i.e. Bałtyk Office building in Poznań. 


\section{CONCLUSIONS}

The above analysis of the examples shows that the vast majority of objects and public spaces selected through the competition are later appreciated. Considering that only $0.07 \%$ of all public procurement is selected through a competition (Urząd Zamówien Publicznych, 2018), it should be noted that there is still a very large potential to increase this value. Unfortunately, there is no data on percentage of public procurement for architectural services selected through competitions vs. tenders. However, it is worth noting that the examples of appreciated objects, whose projects were selected through a competition, are found mainly in large cities. The lack of prizes for projects created in smaller cities or rural communes seems to indicate that the projects implemented there do not rise above the average. This leads to the conclusion that while in larger centers the benefits of competitions have already been realized, that in smaller centers not yet.

The reason for this is certainly the lack of the obligation to use the competition procedure when selecting public projects that were introduced i.e. in Warsaw. Another element is probably the difficulties associated with the organization of the procedure itself, the availability of experts and its costs. However, the basic one seems to be the lack of awareness of the benefits of the architectural competition. For this reason, promoting the competitions among investors outside large cities, would have postive influence on the improving quality of the common spaces.

\section{REFERENCES}

1. Achatzi H. (2017). Konkurs architektoniczny w Niemczech - formy, koszty, wyniki [Architectural competition in Germany - forms, costs, results]. Paper presented at 8. Warszawskie Rozmowy Architektoniczne 2017, Warsaw.

2. Architects' Council of Europe (2018). Architectural Design Contest. Retrieved from: https:// www.ace-cae.eu/policies/

3. Bonnkirch D. (2017). Competitionline Ausschreibungsmonitor 2017 [Competitionline tender monitor 2017]. Paper presented at 8. Warszawskie Rozmowy Architektoniczne 2017, Warsaw.

4. Miasto Stołeczne Warszawa (2017). Policy no 1758/2017 of the Mayor of Warsaw. Retrieved from: http://um.warszawa.pl/.

5. Sejm Rzeczypospolitej Polskiej (1963). Kodeks Cywilny [Civil Law]. Retrieved from: http:// prawo.sejm.gov.pl.

6. Sejm Rzeczypospolitej Polskiej (2017). Ustawa Prawo Zamówień Publicznych [Polish Public Procurement Act]. Retrieved from: http://prawo.sejm.gov.pl/isap.nsf/DocDetails. xsp?id=WDU20170001579.

7. Urząd Zamówień Publicznych (2018). Informacja o Polskim rynku zamówień publicznych na podstawie ogłoszeń opublikowanych w Biuletynie Zamówień Publicznych (stan na dzień 31 grudnia 2018 r.) [Information on the Polish public procurement market based on notices published in the Public Procurement Bulletin (as at 31 December 2018)]. Retrieved from: http:// uzp.gov.pl.

8. Urząd Zamówień Publicznych (2018). Sprawozdanie Prezesa Urzędu Zamówień Publicznych o funkcjonowaniu systemu zamówien publicznych w 2017 r. [Report of the President of the Public Procurement Office on the functioning of the public procurement system in 2017]. Retrieved from: http://uzp.gov.pl. 